\title{
VERBAL COMMUNICATION ANALYSIS IN THE OPRAH WINFREY SHOW
}

\author{
Hani Nurfazrina \\ Department of English Education, University of Kuningan \\ Email: nurfazrina_hani@yahoo.co.id
}

APA Citation: Nurfazrina, H. (2016). Verbal communication analysis in the Oprah Winfrey Show. Indonesian EFL Journal, 2(2), 145-153

Received: 20-05-2016

Accepted: 26-06-2016

Published: 01-07-2016

Abstract: This paper aims at finding verbal communication used by an interviewer and interviewee in Oprah Winfrey Show. The theory used in this research was Levine's and Adelman theory. The data were taken from two different videos of Oprah Winfrey Show. This study used descriptive qualitative method. Based on the result of the research, in the first video, it was found 81 of high involvement and 129 of high considerateness used by Oprah and 54 of high involvement and 125 of high considerateness used by Thich, 21 directness and 20 indirectness used by Oprah and 18 directness and 21 indirectness used by Thich, 3 bowling conversational style applied by Oprah and Thich. In the second video, there were 109 high involvement and 66 of high considerateness used by Oprah, 131 high involvement and 69 of high consideratness used by Alanis, 26 directness and 7 indirectness used by Oprah and 26 of directness and 7 of indirectness used by Alanis, and 1 ping-pong conversation used by Oprah and Alanis. In addition, there were the changes of communication style occured in the conversation between an interviewee and an interviewer in Oprah Winfrey Show that indicate that there are the influences of cultural background towards communication style.

Keywords: Analysis, Verbal Communication, Oprah Winfrey Show

\section{INTRODUCTION}

Verbal communication is the communication delivered by a communicator to the other people by using words. Although verbal communication is effective to share information between one another, but it will be difficult when it is applied in a communication with people who have different cultures. Levine and Adelman (1993, p. 65) state that "cultures influence communication style. Cultural say and do create misunderstandings in conversation among people from different cultures."

Regarding the cultural issue, Oprah Winfrey Show is a good talk show because it always invites people from different country. Oprah Winfrey show hosted by Oprah Gail Winfrey is a talk show program in America which has been shown from 1986 until now. The show has been successful and has a highest rating in almost 24 years shown not only in America but also in all around the world.

This paper would present the verbal communication and the influence of cultural background towards the communication style used in the Oprah Winfrey shows in Thich (4 January 2016) in which Oprah had a discussion with Alanis (September 18, 2014). There were only two people having the conversation including Oprah and a person. The transcript and videos of the Oprah shows were downloaded in order to analyze the characteristics of verbal communication used by them. The verbal communication were classified into conversational involvement, incorrect judgment of character, directness and indirectness, american male and female differences in 


\section{Hani Nurfazrina}

Verbal Communication Analysis in the Oprah Winfrey Show

directness, conversation structure, and ethnocentric judgment (Levine \& Adelman, 1993).

Regarding the conversational involvement, Levine \& Adelman (1993) divided it into high involvement and high considerateness. According to Beaumont (2000), the person who uses high involvement style features, especially faster turn taking and overlap usually will interrupt another turn. On the other hand, the high considerateness style consists of slower speech, slower turn taking, longer pauses between turns, and an avoidance of simultaneous speech.

The incorrect judgment of character is "the judgments that people make about the regional differences within a country are similar to those they make about people from another culture" (Levine \& Adelman, 1993).

Moreover, indirectness is the communication that focus on the relationship. It spends much times to talk and it can be connected to the nonverbal communication. In contrast, the directness style in communication speaks straight to the point and they do not use an introduction or platitude in sharing information to make the other people understand the information. The directness found in American and indirectness found in Asian culture (Chambers, 2012). According to Levine and Adelman (1993), "American women have traditionally been less direct (more polite and soft) than man in making requests, expressing critism and offering opinions."

The conversation structure divided into ping-pong and bowling conversation. The bowling conversation is going on relax and it certainly has a lot of space in their conversation because as we know that the illustration of bowling game itself is hit the ball into same direction and after it finished, we let the other to hit the ball take turns. Meanwhile, the ping-pong conversation illustrates the ping-pong game in conversation (Sakamoto, 1931, p. 389).

The last verbal communication pattern is ethnocentric judgment. Neuliep, Hintz and McCroskey (2005, p. 44) state that "ethnocentric perceive themselves as superior to out groups (e.g., ethnic/racial groups). Hence, when interacting with people from a different culture or ethnic, high ethnocentric are likely to perceive out group members as less attractive than in group members."

Therefore, the presence of various types of verbal communication pattern is interesting to be learnt to avoid misunderstanding between people who are doing conversation with different communication style. The issue raised in this study are:

1. What are the types of verbal communication pattern used by an interviewer and interviewee in Oprah Winfrey show?

2. Does the cultural background influence the style of communication in Oprah Winfrey show?

\section{METHOD}

This study applied a descriptive qualitative method. Descriptive method is a method that aims to make a description, describing in systematic, factual and accurate information on the data, the properties and relations of phenomena under study (Khotari, 2004). Meanwhile, Fraenkel and Wallen (2009, p. 423) state that "qualitative methods are data collected in the form of words or pictures rather than numbers."

The data sources in this study are videos of Oprah Winfrey show downloaded from Youtube. This study uses two episodes of the show those are Thich and Alanis edition.

In analyzing the data, the writer used Morill (2000) theory. The analysis process includes identifying the data based on Levine and Adelman (1993) theory about verbal communication in 
Oprah Winfrey show in both videos, classifying the conversation used by an interviewer and interviewee in Oprah Winfrey show in both videos into types of verbal communication, analyzing the type of verbal communication pattern that consists of conversational structure, incorrect judgment of character, directness and indirectness, American male and female differences in directness, conversation structure and ethnocentric judgment, calculating each type of verbal communication pattern used by an interviewer and interviewee, describing the data analysis based on theory, and the last is concluding the result of the data that have been analyzed.

\section{RESULTS AND DISCUSSION}

This research was conducted to investigate the verbal communication used by an interviewer and an interviewee in Oprah Winfery Show and the infuence of cultural background toward the style of communication. The findings of this research are explained below.

\section{Conversational involement a. High involvement}

Table 1. The frequencies of high involvement characteristics in Thich edition done by Oprah.

\begin{tabular}{|c|c|c|c|}
\hline $\begin{array}{c}\text { High } \\
\text { Involvement } \\
\text { characteristics }\end{array}$ & Utterances & Description & Total \\
\hline $\begin{array}{c}\text { a. Fast rate of } \\
\text { speech }\end{array}$ & $\begin{array}{l}\text { 1. >"How old were you?"< } \\
\text { 2. > "So, this desire to become a monk started when you were } \\
\quad \text { seven years old?"< } \\
\text { 3. >"I never had much thought about a cup of tea."< } \\
\text { 4. > Was in the Princeton."< } \\
\text { 5. > "It was changing?"< } \\
\text { 6. >"That you are a monk."< }\end{array}$ & $\begin{array}{l}\text { In those utterances beside, } \\
\text { Oprah did a fast rate of } \\
\text { speech, because there was no } \\
\text { pause used by her. It is done } \\
\text { when they talked about } \\
\text { Thich's story when he } \\
\text { decided to become a monk } \\
\text { and what are the purposes to } \\
\text { be a monk in the first } \\
\text { segment. }\end{array}$ & 6 \\
\hline $\begin{array}{l}\text { b. Rapid } \\
\text { exchange of } \\
\text { word (heated } \\
\text { conversation) }\end{array}$ & $\begin{array}{l}\text { 1. Thich: "In the beginning they were reluctant because they } \\
\text { thought that the life of a monk is hard and } \\
\text { difficult." } \\
\text { Oprah: "So, this desire to become a monk started when } \\
\text { you were seven years old?" } \\
\text { 2. Thich: "And you enjoy it." } \\
\text { Oprah:"And I enjoyed it. If people follow their passion it's } \\
\text { like following their beginner's mind, so what is the } \\
\text { life of a monk like in this country we just think of it } \\
\text { and I think a lot of people just think it's a lot of } \\
\text { chanting and bringing and being peaceful with } \\
\text { yourself." }\end{array}$ & $\begin{array}{l}\text { Based on the utterances } \\
\text { beside, Oprah did a rapid } \\
\text { exchange of word, because } \\
\text { she showed the fast turn } \\
\text { taking. It proved with when } \\
\text { Oprah taking over the turn, } \\
\text { there was no pause in the } \\
\text { commutation of word } \\
\text { between the last word of } \\
\text { Thich and the first word of } \\
\text { Oprah. It can be seen as } \\
\text { follows: } \\
\text { a. The last word of Thich } \\
\text { "difficult" and the first } \\
\text { word of Oprah "so" } \\
\text { b. The last word of Thich "it" } \\
\text { and the first word of } \\
\text { Oprah "and". }\end{array}$ & 2 \\
\hline
\end{tabular}




\section{Hani Nurfazrina}

Verbal Communication Analysis in the Oprah Winfrey Show

\begin{tabular}{|c|c|c|c|}
\hline c.Interruption & $\begin{array}{l}\text { 1. Thich: "One day I saw a picture of the Buddha on a } \\
\text { Buddhist magazine and he was sitting on the } \\
\text { grass."// } \\
\text { Oprah: //How old were you?" } \\
\text { 2. Thich:"I would not be happy if I cannot become a monk } \\
\text { and that is the feeling. And we call it the } \\
\text { beginner's mind"// } \\
\text { Oprah://"Beginners mind." }\end{array}$ & $\begin{array}{l}\text { In those utterances, Oprah } \\
\text { interrupted what Thich said. } \\
\text { Oprah also did not give a } \\
\text { chance to Thich to finish her } \\
\text { turn. Therefore, Thich did not } \\
\text { finish his turn and his turn is } \\
\text { continued by Oprah. }\end{array}$ & 2 \\
\hline d. Loudness & $\begin{array}{l}\text { 1. "Thank you for the honor of talking to me today thank } \\
\text { you for that. Already just being in your presence for a } \\
\text { short time I feel less stressed than I did when I starting } \\
\text { out the day. Less stressed because you have such a } \\
\text { peaceful are that follows you, that you carry with } \\
\text { yourself. Are you always this content and peaceful?" (L) } \\
\text { 2. "And I enjoyed it. If people follow their passion it's like } \\
\text { following their beginner's mind, so what is the life of a } \\
\text { monk like in this country we just think of it and I think a } \\
\text { lot of people just think it's a lot of chanting and bringing } \\
\text { and being peaceful with yourself." (L) }\end{array}$ & $\begin{array}{l}\text { Based on the utterances in } \\
\text { the second column, Oprah } \\
\text { produced a loud speaking in } \\
\text { her talking, because there } \\
\text { was the raising intonation } \\
\text { done by Oprah and it showed } \\
\text { in the utterances beside that } \\
\text { has been thicked, such as: } \\
\text { a. "Already" and "less } \\
\text { stressed". } \\
\text { b. "People", "follow" } \\
\text { "beginners" and "mind". }\end{array}$ & 2 \\
\hline e.Talk more & $\begin{array}{l}\text { 1. "Thank you for the honor of talking to me today thank } \\
\text { you for that. Already just being in your presence for a } \\
\text { short time I feel less stressed than I did when I starting } \\
\text { out the day. Less stressed because you have such a } \\
\text { peaceful are that follows you, that you carry with } \\
\text { yourself. Are you always this content and peaceful?" } \\
\text { (TM) } \\
\text { 2. "And I enjoyed it people follow their passion it's like } \\
\text { following their begginer's mind, so what is the life of a } \\
\text { monk like in this country we just think of it and I think a } \\
\text { lot of people just think it's it's a lot of chanting and } \\
\text { bringing and being peaceful with yourself." (TM }\end{array}$ & $\begin{array}{l}\text { In the utterances beside, } \\
\text { Oprah talked more, because } \\
\text { she produced the length } \\
\text { sentence that consists of } \\
\text { more than } 35 \text { words, such as: } \\
\text { a.She produced } 61 \text { words. } \\
\text { b. She produced } 53 \text { words. }\end{array}$ & 2 \\
\hline TOTAL & & & 14 \\
\hline \multicolumn{4}{|c|}{ b. High considerateness } \\
\hline $\begin{array}{c}\text { High } \\
\text { Considerateness } \\
\text { characteristics }\end{array}$ & Utterances & Description & Total \\
\hline $\begin{array}{l}\text { a.Speak one at a } \\
\text { time and } \\
\text { refrain from } \\
\text { interrupting }\end{array}$ & $\begin{array}{l}\text { 1. Oprah: "Thank you for the honor of talking to me today } \\
\text { thank you for that. Already just being in your } \\
\text { presence for a short time I feel less stressed than I } \\
\text { did when I starting out the day. Less stressed } \\
\text { because you have such a peaceful are that follows } \\
\text { you, that you carry with yourself. Are you always } \\
\text { this content and peaceful?" } \\
\sqrt{\text { Thich: "This is my training, this is my practice and we try }} \\
\text { to live every moment like that, relax dwelling } \\
\text { peacefully in the present moment and respond to } \\
\text { events with compassion." (R) } \\
\sqrt{ } \text { Oprah: "So in the moment where you are perhaps going to } \\
\text { miss a plane or be late for an appointment or } \\
\text { something is causing you to be stressful you do }\end{array}$ & $\begin{array}{l}\text { In the utterances beside, } \\
\text { Oprah and Thich spoke one at } \\
\text { a time or did the turn taking, } \\
\text { because between them did } \\
\text { not speak all at the same time } \\
\text { and they did not interrupt of } \\
\text { each other. They knew the } \\
\text { time to take the turn and } \\
\text { time to listen. } \\
\text { Beside that the turn taking } \\
\text { here also indicates that } \\
\text { Oprah and Thich refrained } \\
\text { from interrupting, because as } \\
\text { said before that speak one at }\end{array}$ & $\begin{array}{l}(\sqrt{ }) \\
\text { T: } 3 \\
0: 2 \\
(R) \\
\text { T: } 3 \\
0: 2\end{array}$ \\
\hline
\end{tabular}




\begin{tabular}{|c|c|c|c|}
\hline & $\begin{array}{l}\text { what." (R) } \\
\sqrt{ } \text { Thich: "Go back to my breathing and try to be in that } \\
\text { moment deeply because there is a possibility to } \\
\text { handle every kind of event and the essential is to } \\
\text { keep the peace in yourself." }(\mathrm{R}) \\
\sqrt{ } \text { Oprah: "So let's start with } 1926 \text { born in Vietnam, any } \\
\text { wonderful memories that you can share your } \\
\text { childhood, your favorite childhood memory?" }(\mathrm{R}) \\
\sqrt{ } \text { Thich: "One day I saw the picture of the Buddha on a } \\
\text { Buddhist magazine and he was sitting on the } \\
\text { grass." (R) }\end{array}$ & $\begin{array}{l}\text { a time itself is the talking that } \\
\text { ongoing and arranged } \\
\text { without an interruption. It } \\
\text { can be called refrain from } \\
\text { interrupting whether it is } \\
\text { fast or slow turn taking. }\end{array}$ & \\
\hline b. Politeness & $\begin{array}{l}\text { 1. Oprah } \\
\text { 1. "Thank you for the honor of talking to me today thank } \\
\text { you for that. Already just being in your presence for } \\
\text { a short time I feel less stressed than I did when I } \\
\text { starting out the day. Less stressed because you have } \\
\text { such a peaceful are that follows you, that you carry } \\
\text { with yourself. Are you always this content and } \\
\text { peaceful?" }\end{array}$ & $\begin{array}{l}\text { 1. Oprah } \\
\text { a. The utterance said by } \\
\text { Oprah showed the } \\
\text { politeness speaking. It can } \\
\text { be seen by the context of } \\
\text { the sentence itself, such as } \\
\text { in the first utterance, } \\
\text { Oprah said "Thank you for } \\
\text { the honor of talking to me } \\
\text { today thank you for that." } \\
\text { It was polite because } \\
\text { Oprah showed a modesty } \\
\text { talking and respect to } \\
\text { another and it include of } \\
\text { the negative face in } \\
\text { politeness strategies. }\end{array}$ & $0: 1$ \\
\hline $\begin{array}{l}\text { c. Positive } \\
\text { respectful } \\
\text { response }\end{array}$ & $\begin{array}{l}\text { a. Oprah } \\
\text { 1. Thich: "In the beginning they were reluctant because they } \\
\text { thought that the life of a monk is hard and } \\
\text { difficult." } \\
\text { Oprah: "So, this desire to become a monk started when } \\
\text { you were seven years old?" PR } \\
\text { 2. Thich: "Everyone has a desire, but the desire to transform } \\
\text { oneself. To transform one's affliction, suffering, in } \\
\text { order to get free and help other people and change } \\
\text { the world. That is a good desire." } \\
\text { Oprah: "It is what a lot of people refer to as passion when } \\
\text { you're passionate about your work." PR }\end{array}$ & $\begin{array}{l}\text { a.Oprah } \\
\text { 1. Oprah responded the } \\
\text { talking through clarified } \\
\text { her understanding about } \\
\text { Thich's answer from her } \\
\text { question or made a } \\
\text { conclusion of Thich's } \\
\text { answer, therefore it } \\
\text { indicates that Oprah was } \\
\text { pay attention of Thich's } \\
\text { talking and it indicates a } \\
\text { positive respectful } \\
\text { response too. and a statement } \\
\text { 2. Oprah made } \\
\text { through clarified her } \\
\text { understanding of Thich's } \\
\text { talking. It is a good } \\
\text { information too for the } \\
\text { listener, therefore it } \\
\text { indicates that Oprah was } \\
\text { pay attention of Thich's } \\
\text { talking and intends a } \\
\text { positive respectful } \\
\text { response too. }\end{array}$ & $0: 2$ \\
\hline TOTAL & & $\begin{array}{l}\text { Thich } \\
\text { Oprah }\end{array}$ & $\begin{array}{l}6 \\
7\end{array}$ \\
\hline
\end{tabular}

Table 2 showed the characteristics of high considerateness communication style done by Oprah.
From the table, it can be seen that Oprah produced 7 and Thich produced 6 characteristics of high considerateness. 


\section{Hani Nurfazrina}

Verbal Communication Analysis in the Oprah Winfrey Show

\section{Directness and Indirectness}

\section{a. Directness}

Table 3. The frequency of directness in Alanis edition done by Alanis in the first segment.

\begin{tabular}{|c|c|}
\hline \multicolumn{2}{|l|}{ Directness } \\
\hline Utterances & Description \\
\hline $\begin{array}{l}\text { 1. Oprah: "So many people first came to know you through } \\
\text { "Jagged Little Pill" wow. That was nearly } 20 \text { years } \\
\text { ago and now you've just recently turned } 40 \text { and call } \\
\text { that a seminal moment. I thought "Jagged Little Pill" } \\
\text { that was a seminal moment was it?" } \\
\text { Alanis: "Yes, that was a seminal moment that I'm only able } \\
\text { to process now for having PTSD my way through the } \\
\text { last } 20 \text { years in response to the "My Hump" that was } \\
\text { that chapter for sure." DIRECT }\end{array}$ & $\begin{array}{l}\text { Based on the utterances beside, indicate } \\
\text { that Alanis did a direct speech because } \\
\text { when Oprah stated the questions, Alanis } \\
\text { always answered it get to the point and did } \\
\text { not beat around the bush. She always talked } \\
\text { in essential. It was done in the first segment } \\
\text { when Oprah and Alanis talked about } \\
\text { Alanis's album and her personal psyche } \\
\text { experience. }\end{array}$ \\
\hline $\begin{array}{l}\text { 2. Oprah: "So "Jagged Little Pill" came out. And it just turned } \\
\text { you into a phenomenon?" } \\
\text { Alanis: "Yes, we were playing } 100 \text { seater clubs and then we } \\
\text { were playing stadiums so went from zero to } 6503.5 \\
\text { seconds." DIRECT }\end{array}$ & \\
\hline $\begin{array}{c}\text { TOTAL } \\
\end{array}$ & \\
\hline
\end{tabular}

Table 3 showed the directness style of verbal communication used by
Alanis. It can be seen that there are 2 times of directness done by Alanis.

\section{b. Indirectness}

Table 4. The frequency of indirectness in Thich edition done by Alanis in the first segment.

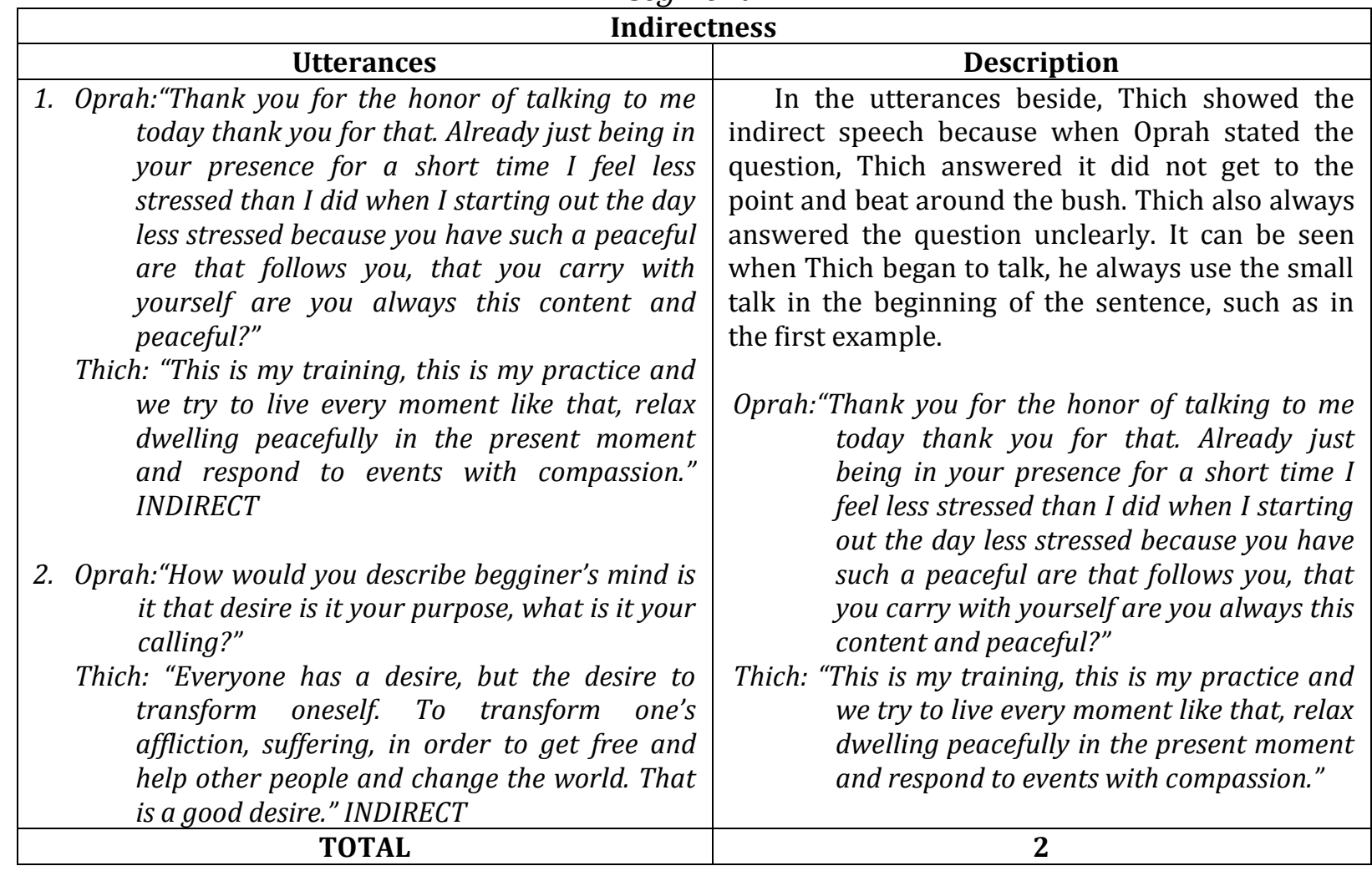

Table 4 showed the indirectness style of verbal communication used by
Thich. The table showed that there are 2 times of indirectness done by Thich. 
3. Conversation structure

\section{a. Ping-pong conversational style}

Table 5. The frequency of ping-pong conversational style in Alanis edition done by

Oprah and Alanis in the third segment.

\begin{tabular}{|c|c|}
\hline \multicolumn{2}{|c|}{ Ping-pong conversational style } \\
\hline Utterances & Description \\
\hline $\begin{array}{l}\text { Oprah: "So you had keeping love you find. I read well } \\
\text { I had you know I had horrible on here in like } \\
\text { whenever he wrote getting the love you want. } \\
\text { I would not still be in relationship with seven } \\
\text { had enough."// } \\
\text { Alanis: //"We need that."// } \\
\text { Oprah: //"That book is the best relationship book } \\
\text { ever."// } \\
\text { Alanis: //"It explains at all."// } \\
\text { Oprah: // "It explains everything."// } \\
\text { Alanis: //"Everything. And it's so merciful and it's so } \\
\text { intelligent and it blends for me that stages of } \\
\text { development chart not only explains how to } \\
\text { navigate the relationship but how to navigate } \\
\text { this relationship." } \\
\text { Oprah: "Absolutely." }\end{array}$ & $\begin{array}{l}\text { The conversation beside, indicate that } \\
\text { Oprah and Alanis showed ping-pong } \\
\text { conversational style. } \\
\text { For the first time, Oprah informed the } \\
\text { book that has been read by her to Alanis and it } \\
\text { indicates that Oprah has the ball because she } \\
\text { started to talk "So you had keeping love you find. I } \\
\text { read well I had you know I had horrible on here in } \\
\text { like whenever he wrote getting the love you want. I } \\
\text { would not still be in relationship with seven had } \\
\text { enough" and after that, Alanis interrupted Oprah } \\
\text { said because Oprah produced a lot of sentences, } \\
\text { therefore it indicates that Oprah monopolized the } \\
\text { conversation. } \\
\text { After that both of them stopped doing a } \\
\text { ping-pong conversational style illustration until } \\
\text { Oprah said absolutely when Alanis finished talking } \\
\text { about the book that have read by her too. }\end{array}$ \\
\hline & \\
\hline
\end{tabular}

The table above showed that Alanis and Oprah applied the ping-pong conversational style as the first type of conversation structure. This ping-pong style only occurred in the third segment with duration 04:34 minutes as much as 1 time.

\section{b. Bowling conversational style}

Table 6. The frequency of bowling conversational style in Thich edition done by Oprah and Thich in the first segment.

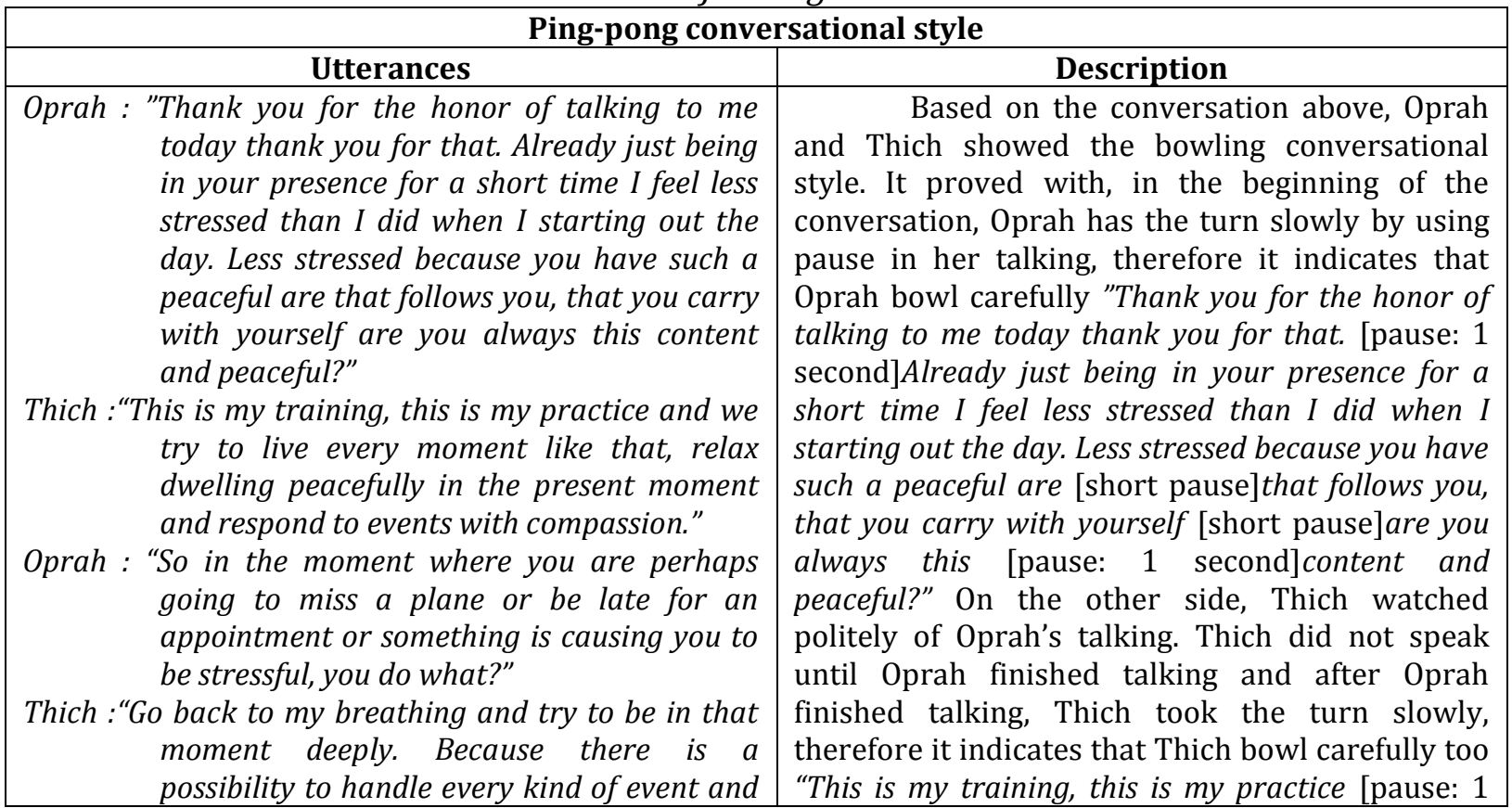


Hani Nurfazrina

Verbal Communication Analysis in the Oprah Winfrey Show

\begin{tabular}{|c|l|}
\hline the essential is to keep the peace in yourself." & $\begin{array}{l}\text { second] and we try to live every moment like that, } \\
\text { relax [short pause]dwelling [pause: 1 } \\
\text { second]peacefully in the present moment [pause: } 1 \\
\text { second] and[pause: 1 second] respond to events } \\
\text { with[short pause] compassion." It was done } \\
\text { continually. }\end{array}$ \\
\hline TOTAL & \multicolumn{1}{|c|}{} \\
\hline
\end{tabular}

Table 6 showed the bowling conversational style as one of the part of conversation structure in verbal communication. It occurred one time in the first segment, with duration 11: 39 minutes in Thich edition done by Oprah and Thich.

The result of the analysis relating to verbal communication used is shown in the table below.

Table 7. Frequency of verbal communication used in Oprah Winfrey Show.

\begin{tabular}{|c|c|c|c|c|c|}
\hline \multirow{2}{*}{ No } & \multirow{2}{*}{ Aspect } & \multicolumn{2}{|c|}{ Thich edition } & \multicolumn{2}{|c|}{ Alanis edition } \\
\hline & & Thich & Oprah & Alanis & Oprah \\
\hline \multirow[t]{3}{*}{1} & Conversational involvement & & & & \\
\hline & a. High involvement & 54 & 81 & 131 & 109 \\
\hline & b. High considerateness & 125 & 109 & 69 & 66 \\
\hline \multicolumn{2}{|r|}{ Total } & \multicolumn{2}{|c|}{369} & \multicolumn{2}{|c|}{375} \\
\hline 2 & Incorrect judgment of characters & 0 & 0 & 0 & 0 \\
\hline \multirow[t]{2}{*}{3} & a. Directness & 18 & 21 & 24 & 26 \\
\hline & b. Indirectness & 21 & 20 & 8 & 7 \\
\hline \multicolumn{2}{|r|}{ Total } & \multicolumn{2}{|c|}{$\begin{array}{l}\text { Directness: } 39 \\
\text { Indirectness: } 41 \\
\end{array}$} & \multicolumn{2}{|c|}{$\begin{array}{l}\text { Directness: } 50 \\
\text { Indirectness: } 15\end{array}$} \\
\hline 4 & $\begin{array}{l}\text { American male and female differences in } \\
\text { directness }\end{array}$ & 0 & 0 & 0 & 0 \\
\hline \multirow[t]{3}{*}{5} & Conversation structure & & & & \\
\hline & a. Ping-pong conversational style & \multicolumn{2}{|c|}{0} & \multicolumn{2}{|c|}{1} \\
\hline & b. Bowling conversational style & \multicolumn{2}{|c|}{3} & \multicolumn{2}{|c|}{0} \\
\hline \multicolumn{2}{|r|}{ Total } & \multicolumn{2}{|c|}{3} & \multicolumn{2}{|c|}{1} \\
\hline 6 & Ethnocentric judgment & 0 & 0 & 0 & 0 \\
\hline
\end{tabular}

Based on the table above, there are three types of verbal communication employed in both videos. The first type is conversational involvement. It occured 369 times that contains high involvement and high considerateness in Thich edition and 375 times in Alanis edition. The second type was directness and indirectness. The directness occurred 39 times while indirectness occurred 41 times in Thich edition. In addition, the directness occurred 50 times and 15 times for indirectness in
Alanis edition. The last type was conversation structure. Conversation structure occurred 3 times. It consists of ping-pong and bowling conversation in Thich edition. Meanwhile in Alanis edition, it only occurred once.

The second aspect that was being analyzed was about the influence of cultural background towards the communication style. This analysis triggered by the fact that misunderstanding and the changes of communication style can be happened because of cultural background 
differences. As result, in Thich and Alanis edition, there was no misunderstanding occurred, but their communication style changed because of their cultural background. In analyzing this influences, the researcher used Tannen (2001) theory. According to Tannen (2001), two countries that usually use the high involvement and directness communication are America and Canada. Moreover, the Ping-pong communication style appeared in America and Bowling communication style appear in Japan. In Thich edition, the interviewee comes from Vietnam and he is an immigrant from America and Oprah herself comes from America. In that show, Thich sometimes produced high involvement style as much as 54 times. On the other hand, Oprah showed the high considerateness style that was higher than high involvement. Oprah used 109 times of high considerateness. In terms of directness, Thich sometimes showed direct speech and Oprah showed indirect speech. Meanwhile, both of them showed the bowling conversation style which was Japanese communication pattern.

In Alanis edition, Alanis and Oprah sometimes showed the high considerateness style and indirectness. Besides, Alanis also showed ping-pong conversational style which was American communication pattern.

\section{CONCLUSION}

This research focuses on analyzing the type of verbal communication used by the interviewer and interviewee in Oprah Winfrey Show and the influence of cultural background towards the communication style in Oprah Winfrey Show. Here, the researcher takes two videos of Opah Winfrey Show; Thich and Alanis edition in Super Soul Sunday. As result, it was found that the types of verbal communication occured in Oprah Winfrey Show conversation are conversational involvement, direct and indirect, and conversation structure. The conversational involvement that occured in that videos consists of high involvement and high considerateness, direct and indirect speech, and the conversation structure that consists of ping-pong and bowling conversation. Moreover, the cultural background that influence the style of communication occured through the changes of communication style of each person in Oprah Winfrey Show.

\section{REFERENCES}

Chambers, B. (2012). Intercultural communication handbook. CESLM Intercultural Project.

Fraenkel, J., \& Wallen, N. (2009). How to design and evaluate research in education ( $7^{\text {th }} \mathrm{Ed}$ ). New York: Mc Graw-Hill.

Khotari, C. R. (2004). Research methodology methods and techniques (2nd Ed). New Delhi: New Age Internasional (P), Ltd.

Levine, D. R., \& Adelman, M. B. (1993). Beyond language cross cultural communication (2nd Ed.). Englewood: Prentice Hall, Inc.

Neuliep, Hintz, \& McCroskey. (2005). The influence of ethnocentrism in organizational contexts: Perceptions of interviewee and managerial, attractiveness, credibility, and effectiveness. Morgantown: Eastern Communication Association.

Sakamoto, N. M. (1931). Build understanding conversational ball games. Hawai: Go Online.

Tannen, D. (2001). You just don't understand: Women and men in conversation. William Morrow Paper Back. 